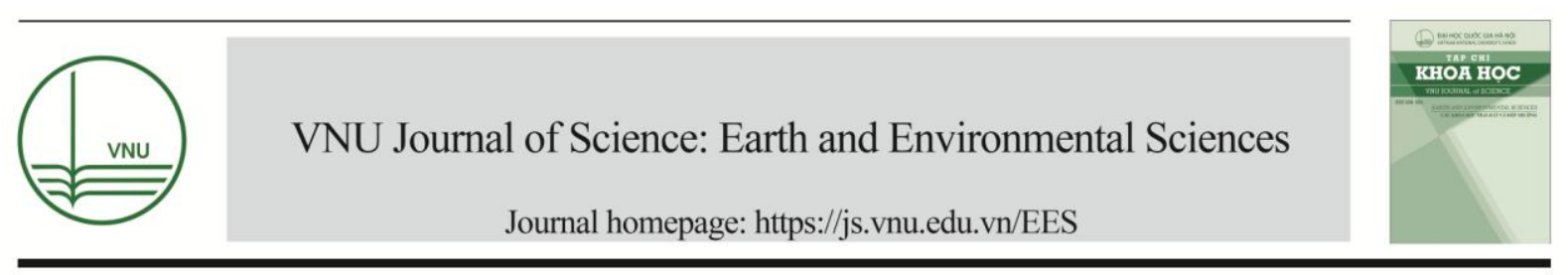

\title{
Effects of Monsoon Activity on Monthly Phytoplankton Blooms in the Gulf of Thai Land in El Nino Year 2002
}

\author{
Le Van Thien * \\ Hanoi University of Natural Resources and Environment, Cau Dien, Nam Tu Liem, Hanoi, Vietnam
}

Received 19 March 2018

Revised 14 April 2018; Accepted 18 April 2018

\begin{abstract}
The Gulf of Thailand is a semi-closed Gulf on the west and southwest side of the Indochina Penisula and experiences reversal monsoon. The object of the present study is to investigate monthly and spatial distributions of the phytoplankton in the Gulf of Thailand during whole El Nino year 2002 by using remote-sensing measurements of chlorophyll-a (Chl-a) and surface wind vectors. Results show that monthly and spatial variations of the phytoplankton blooms are primarily associated with the monsoonal winds. In general, the average monthly Chl-a concentrations were quite low $\left(<0.5 \mathrm{mg} \mathrm{m}^{-3}\right)$ most area of the Gulf, with a belt of higher Chl-a concentrations along the coast during throughout year. Phytoplankton blooms extensively offshore in the near-coastal area of the Gulf in January and February, which is consistent with the winter northeast monsoon. In particular, one peak of Chl-a concentrations was observed in December. Areas with higher Chl-a concentrations along the coast were observed in both winter and summer monsoon months.
\end{abstract}

Keywords: Phytoplankton blooms, Monsoon, Gulf of Thailand, El Nino.

\section{Introduction}

The Gulf of Thailand is a semi closed sea and on the west and southwest side of the Indochina Penisula (Fig 1). The population in the coastal area of Gulf of Thailand is large, and the Gulf of Thailand is a rapidly developing area both in economics and society, particularly in aquaculture sectors. Physical, chemical and biological processes in the ocean are in an

\footnotetext{
* Tel.: 84-1676171337.

Email: thienmet@gmail.com

https://doi.org/10.25073/2588-1140/vnunst.4232
}

intimated relationship [1, 2]. The physical properties such as the horizontal distribution of bottom cold, saline, and heavy water masses in the Gulf of Thailand could be related to the incidence and direction of monsoon winds in that gulf [3]. The monthly variation of the heat flux could be correlated with the sea surface wind in the Gulf of Thailand [4]. Chlorophyll-a is an index of phytoplankton biomass. However, characteristics of chlorophyll-a and its distribution associated with monsoon activity have remained unknown or poorly known for most of the gulf. In the present study, we investigated monthly and spatial 
variations of Chlorophyll-a (Chl-a) and sea surface wind conditions in the Gulf of Thailand during the whole El Nino year 2002 by examining satellite measurements.

\section{Study area and satellite data, and methods}

\subsection{Study area}

The study region is the Gulf of Thailand (area in Fig. 1, $100^{\circ} \mathrm{E}-104^{0} \mathrm{E}, 6^{0} \mathrm{~N}-12^{\circ} \mathrm{N}$ ). The average depth of Gulf of Thailand is about $40 \mathrm{~m}$. This region experiences reversal monsoons with the southwest monsoon in the summer and northeast monsoon in the winter.

\subsection{Satellite-derived chlorophyll-a}

Sea viewing Wide Field-of View Scanner (SeaWiFS) derived Chlorophyll-a was processed using the Ocean Color 4-band algorithm (OC4) [5, 6]. Monthly averaged Chla concentrations with $3 \times 3 \mathrm{~km}$ spatial resolution were obtained and processed for the study region. Ocean Color and Temperature Scanner (OCTS) aboard Advanced Earth Observing Satellite observed the Chl-a concentration in the surface layer from October 1996 to June 1997 with quality similar to that of SeaWiFS [7]. SeaWiFS-derived Chl-a concentrations are consistent with survey measurement in most area in the western South China Sea, including coastal waters [2].

\subsection{Satellite-derived surface vector winds}

Sea surface vector winds have been measured from the microwave scatterometers [8]. We used 0.5-degree monthly mean wind fields obtained from the QuickBird satellite which was launched in June 1999. QuikScat is a radar device that transmits radar pulses down to the Earth's surface and then measures the power that is scattered back to the instrument. Wind speed and direction over the ocean surface are obtained from measurements of the QuikScat backscattered power [8].

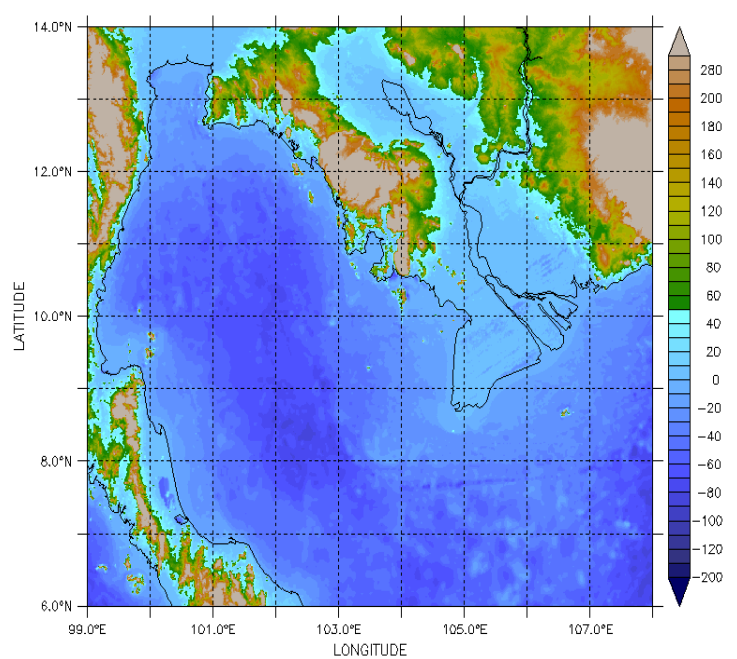

Figure 1. Bathymetry of the study area.

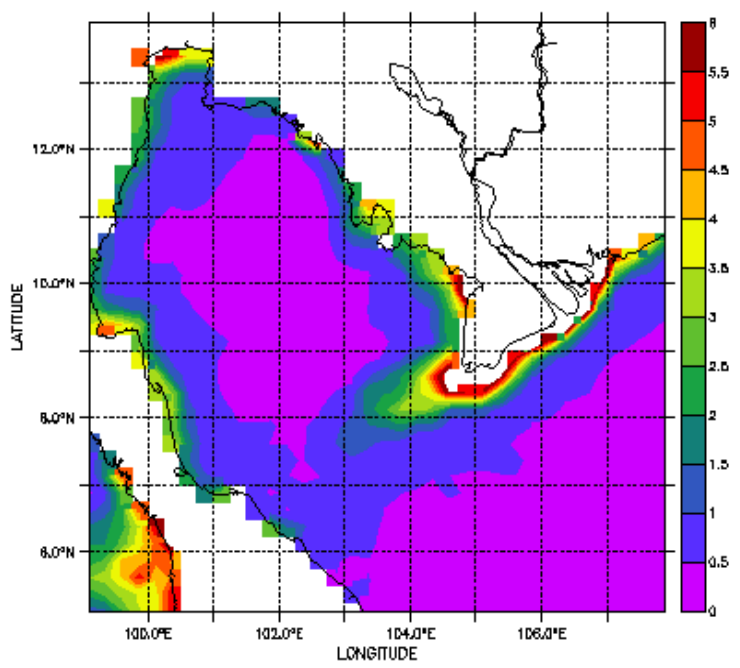

monthly chlorophyll conc. (miligrams/m 3 )

Figure 2. Monthly mean SeaWiFS Chl-a for January 2002.

\section{Conditions of surface winds and Chl-a distributions and phytoplankton blooms}

The monthly variations and spatial distributions of Chl-a concentrations and surface winds from January to December 2002 were analyzed and shown by some representative figures. During January, the Chl-a in the center of the Gulf is very low $(<0.5$ $\left.\mathrm{mg} \mathrm{m}^{-3}\right)$. However, a belt of high Chl-a 
concentrations along the coast of the Gulf (Fig. 2) and strong northeast monsoon winds (> $7 \mathrm{~m} / \mathrm{s}$ ) were observed on the south side of the gulf below latitude 9N (Fig 3). Particularly, the strong phytoplankton blooms with high Chl-a concentrations $\left(>1.5 \mathrm{mg} \mathrm{m}^{-3}\right.$ ) appeared in the offshore region with a tongue shape in this month (Fig. 3).

These characteristics were found to be similar in February although the extended area of high Chl-a and the magnitudes of winds were smaller than in January (not shown). The distribution of Chl-a concentration has similar patterns with the coastal phytoplankton blooms and values during March and April (not shown). The weaker south and southeast monsoon winds dominated almost entire the gulf and ranged from $4-5.5 \mathrm{~m} / \mathrm{s}$ during these two months (not shown). The bloom strengthens in May along the eastern coast area and the southwest monsoon onset was obvious as the monsoon winds started changing in the direction to south and southwest all over the Gulf (not shown). The bloom developed in the eastern gulf and weakened in the western gulf along the coastal lines from June to September (Fig. 4).

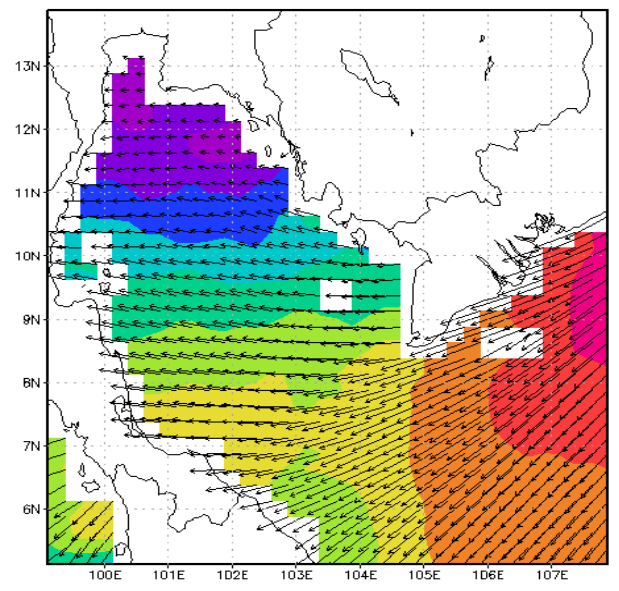

Figure 3. Monthly mean QuikScat surface vector winds for January 2002.

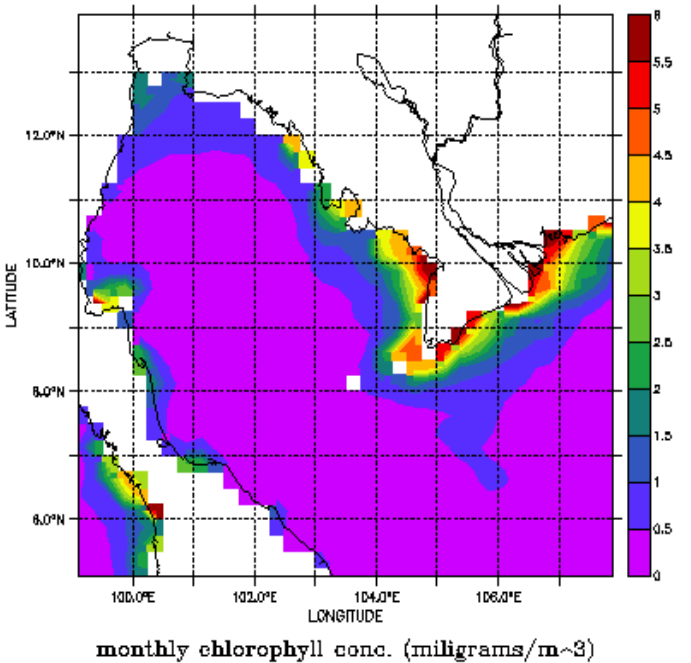

Figure 4. Monthly mean SeaWiFS Chl-a for July 2002.

The prevailing winds in the gulf were very strong southwesterly winds with surface wind speed reached from $5-10 \mathrm{~m} / \mathrm{s}$ during these months (Fig. 5).

The bloom seems a little weakened in October (not shown). The monthly mean winds lessened during this month (not shown). A longer intense bloom was found in November and December near the coast (Fig. 6).
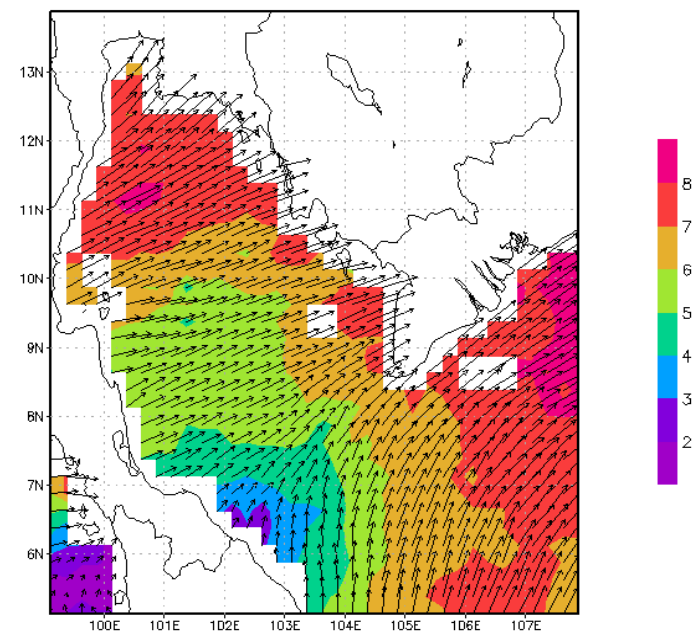

Figure 5. Monthly mean QuikScat surface vector winds for July 2002. 
The strong extended bloom father offshore has a similar patch of high Chl-a in both December and January. This behavior of phytoplankton is the same as shown in November and February. It is worth to note that the prevailing winds were the strongest northeast winds through the year in these two months (Fig. 7).

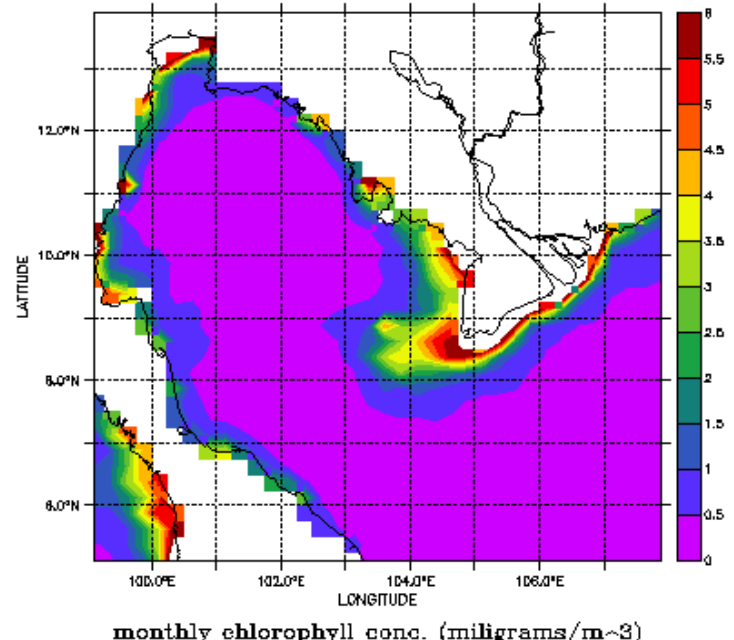

Figure 6. Monthly mean SeaWiFS Chl-a for December 2002.

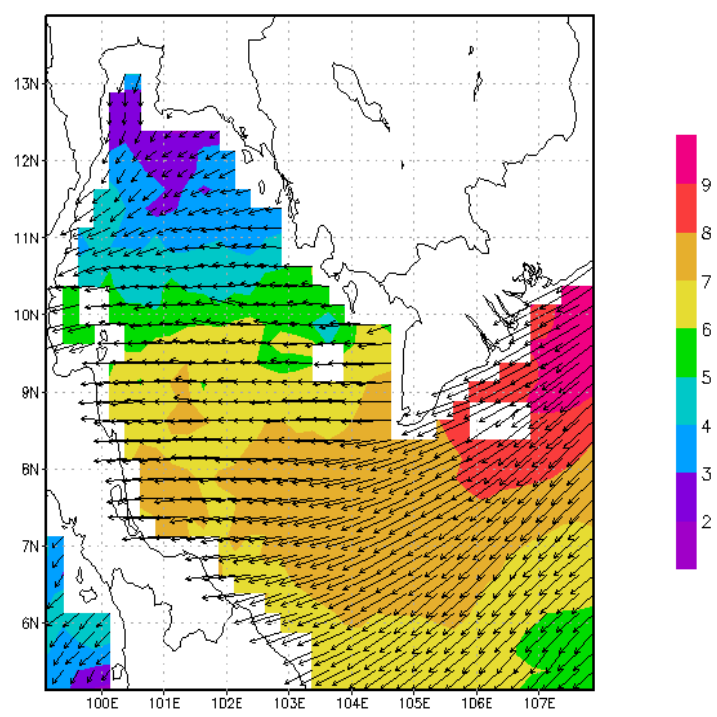

Figure 7. Monthly mean QuikScat surface vector winds for December 2002.

\section{Discussion}

In general, Chl-a concentration in the coastal area of the Gulf of Thailand was higher than that in the offshore area. The phytoplankton blooms with high Chl-a concentration $\left(>1.5 \mathrm{mg} \mathrm{m}^{-3}\right)$ appeared in the extended offshore regions in January, February, November, and December and decreased during transition month in April. In the center area of the Gulf, Chl-a concentrations were usually relatively low $\left(<0.5 \mathrm{mg} \mathrm{m}^{-3}\right)$ throughout the year. In the coastal zones, Chl-a concentrations were generally high throughout the year and further enhanced during the strong northeast winter monsoon winds of November, December and January and strong southwest summer monsoons winds of June-September. In particular, Chl-a concentration was peak during the strong northeast monsoon winds in January, November, and December.

The Gulf of Thailand dominates by the Asian monsoon, which obviously illustrates the reversed wind direction in a year with northeast winds in the winter and southwest winds in the summer.

So hat factors that may cause the bloom in this gulf? In this section, we discuss some physical processes that may contribute to the bloom. First, the coastal upwelling which is the consequence of the offshore transport of wind drove surface current due to the Coriolis effects. The upward movement of waters causes the intense phytoplankton blooms. However, the northeasterly and southwesterly monsoon winds during months in this year do not favor coastal upwelling along the coast. Another process that contributes to the bloom is from Ekman pumping. This Ekman pumping was thought to cause strong upward motion. Upwelling by Ekman pumping during the monsoon activity is able to enhance $\mathrm{Chl}-\mathrm{a}$ concentration and induce the bloom. A comprehensive study is required for this elucidation when mean Ekman pumping calculated from winds. We will leave it for a future study. 
In addition, many previous papers have demonstrated that vertical mixing is associated with abundant plant and animal biomass [9-11]. Entrainment of nutrient-rich water by wind mixing may act to enhance phytoplankton blooms during monsoon in this gulf. The strong winds during northeast monsoon in the winter mix water to deeper depths and thus bring nutrients to the mixed layer induced high Chl-a. During the mature phase of El Nino, [12] showed that a decrease in cloudiness over the Gulf induces an increase in the shortwave radiation in November. Thus the strong winds during the northeast winter monsoon may mix water to deeper depths and consequently induct nutrients to the mixing layer resulting in high Chl-a in the clear sky period of El Nino year. Thus, the importance of monsoonal winds in the Gulf as a physical process which may enhance Chl-a appears to be a major forcing factor during the northeast monsoon in this El Nino year over the Gulf of Thailand.

\section{References}

[1] Chaturvedi N., Narain A., and Pandey P.C., 1998. Phytoplankton pigment/temperature relationship in the Arabian Sea, Indian J. Mar. Sci, 27, p.286-291.

[2] Tang D.L., Kawamura H., Dien T.V., and Lee M. A., 2004b. Offshore phytoplankton biomass increases and its oceanographic causes in the South China Sea, Mar. Ecol. Prog. Ser, 268, p.31-41.
[3] Yanagi T., Sachoemar S.I., Takao T., and Fujiwara S., 2001. Seasonal variation of stratification in the Gulf of Thailand, J. Oceanogr, 57, p.461-470.

[4] Stansfield K., and Garrett C., 1997. Implications of the salt and heat budgets of the Gulf of Thailand. J. Mar. Res, 55, p.935-963.

[5] O'Reilly J.E., et al. 2000. Ocean color chlorophyll an algorithm for SeaWiFS, OC2, and OC4: Version 4, in SeaWiFS Postlaunch Calibration and Validation Analyses: Part 3, edited by S. B. Hooker, and E. R. Firestone, NASA Tech. Memo, 2000-206892(11), p.9-23.

[6] O'Reilly J.E., Maritorena S., Mitchell B. G., Siegel D.A., Carder K.L., Garver S.A., Kahru M., and McClain C., 1998. Ocean color chlorophyll algorithms for SeaWiFS, J. Geophys. Res, 103(24), p.937-24,953.

[7] Kawamura H., and OCTS Team, 1998. OCTS mission overview, J. Oceanogr, 54, p.383-399.

[8] Wentz F.J., Smith D.K., Mears C.A., and Gentemann C.L, 2001. Advanced algorithms for QuikScat and SeaWinds/AMSR, paper presented at IGARSS '01, NASA, Washington, D. C.

[9] McGowan J.A., and Hayward T.L., 1978. Mixing and oceanic productivity, Deep Sea Res, 25, p.771-793.

[10] Marra J., 1980. Vertical mixing and primary productivity, in Primary Productivity in the Sea, edited by P. G. Falkowski, p. 121-137, Plenum, New York.

[11] Banse K., and McClain C.R., 1986. Satelliteobserved winter blooms of phytoplankton in the Arabian Sea, Mar. Ecol. Prog. Ser, 34, p. 201-211.

[12] Wang C., Wang W., Wang D., and Wang Q., 2006. Interannual variability of the South China Sea associated with El Niño, J. Geophys. Res, 111, C03023, doi:10.1029/2005JC003333. 


\title{
Ảnh hưởng của hoạt động gió mùa đến sự bùng nổ thực vật phù du trong các tháng của năm El Nino 2002 ở Vịnh Thái Lan
}

\author{
Lê Văn Thiện \\ Truờng Đại học Tài nguyên và Môi truờng Hà Nội, Cầu Diễn, Nam Tù Liêm, Hà Nội, Việt Nam
}

Tóm tắt: Vịnh Thái Lan là một vịnh gần như khép kín ở phía Tây Nam và Tây của bán đảo Đông Dương và là vịnh có sự dịch chuyển ngược chiều của hoạt động gió mùa. Mục tiêu của nghiên cứu này là nghiên cứu sự phân bố theo không gian và theo các tháng của thực vật phù du ở Vịnh Thái Lan trong toàn bộ một năm El Nino 2002 bằng việc sử dụng số liệu quan trắc từ vệ tinh của nồng độ chlorophyll-a (Chl-a) và véc tơ gió bề mặt. Các kết quả nghiên cứu chỉ ra rằng sự biến đổi theo không gian và theo các tháng của việc bùng nổ thực vật phù du là chủ yếu liên quan đến sự hoạt động của gió mùa. Nhìn chung, nồng độ Chl-a trung bình hằng tháng là khá thấp $\left(<0,5 \mathrm{mg} \mathrm{m}^{-3}\right)$ ở hầu hết các khu vực trong Vịnh, tuy nhiên có một dải có nồng độ Chl-a cao hơn dọc theo ven biển Vịnh trong suốt cả năm. Sự bùng nổ thực vật phù du mở rộng ra ngoài khơi trong các khu vực gần ven biển của Vịnh trong tháng 1 và tháng 2 , đây cũng là tháng phù hợp với hoạt động của gió mùa đông bắc. Đặc biệt, nồng độ Chl-a lớn nhất được quan trắc thấy vào tháng 12 . Các khu vực có nồng độ $\mathrm{Chl}$-a cao hơn dọc theo ven biển là được quan trắc thấy trong cả các tháng mùa đông và các tháng mùa hè.

Tù khóa: Bùng nổ thực vật phù du, gió mùa, Vịnh Thái Lan, El Nino. 